Развитие информационных технологий и их внедрение в судопроизводство является одним из важнейших направлений реформирования гражданского процесса. Оно направлено то, чтобы упростить и повысить оперативность судопроизводства. Однако применение их в гражданском судопроизводстве не должно становиться самоцелью.

Основной задачей законодателя в данной области должно стать нахождение максимально эффективного, надёжного, а главное, оптимального механизма извещения участников гражданского процесса. Безусловно, при реализации каждого способа извещения могут возникать проблемы, поэтому в целях их предотвращения наиболее разумным, на наш взгляд, будет разработка и утверждение специальной инструкции, которая подробно урегулирует способы извещения и механизм их применения на законодательном уровне.

$$
* * *
$$

1. Гражданский процессуальный кодекс Российской Федерации от 14.11.2002. (ред. от 28.12. 2017) № 138-Ф3 // Российская газета. - 2002 г. - № 220.

2. Постановление Пленума Верховного Суда РФ от 09.02.2012 N 3 (ред. от 19.12.2017) "О внесении изменений в некоторые постановления Пленума Верховного Суда Российской Федерации" [Электронный pecypc]. URL: http://www.consultant.ru/document/cons_doc_LAW_125959/(Дата обращения: 05.03.2018).

3. Приказ Судебного департамента при Верховном Суде РФ от 25.12.2013 г. № 257 "Об утверждении Регламента организации извещения участников судопроизводства посредством СМС-сообщений" // Бюллетень актов по судебной системе". - 2014 г. - № 2.

4. Гришанина Е.М. Возможность использования информационных технологий для извещения участников гражданского судопроизводства [Текст] / Е.М. Гришанина // Право и суд в современном мире сборник статей по материалам XIII ежегодной Международной научно-практической конференции студентов и молодых ученых. Российский государственный университет правосудия; Под редакцией Э. Л. Лещиной, Е. М. Офман. - 2016. - №5. С. 135-141.

5. Гусев В.Г. «Проблема извещения участников гражданского судопроизводства» - [Электронный pecypc]. URL: http://ex-jure.ru/law/news.php?newsid=863 (Дата обращения: 05.03.2018).

6. Егоров Е.В. Актуальные проблемы системы извещения участников судопроизводства посредством СМС-сообщений // Администратор суда. - 2012 г. - № 4.

7. Котоян М.А., Страхов С.Е. Проблемы извещения лиц, участвующих в гражданском судопроизводстве // Молодежный научный форум: Общественные и экономические науки: электр. сб. ст. по мат. XXXIX междунар. студ. науч.-практ. конф. - № 10(39). - [Электронный ресурс]. URL:https://nauchforum.ru/archive/MNF_social/10(39).pdf (дата обращения: 09.03.2018)

8. Саврасова Л.Н., Мешалкина А.В. Извещение участников гражданского судопроизводства с применением информационных технологий // Международный студенческий научный вестник. $2017 . \quad-\quad$ № $\quad 6 . \quad$ C. $161 . \quad$ [Электронный pecypc]. URL: https://www.eduherald.ru/ru/article/view?id=17941(Дата обращения: 06.03.2018).

\title{
Дараган В.A. \\ Применение теста на пропорциональность при рассмотрении конституционных жалоб
}

Дальневосточный федеральный университет (Россия, Владивосток)

doi:10.18411/spc-20-04-2018-07

idsp: 000001:spc-20-04-2018-07

Основанием к разбирательству по жалобе в Конституционном Суде РФ служит «неопределенность в вопросе о том, соответствует ли Конституции ... закон» (ч. 1 ст. 36 ФКЗ «О Конституционном Суде РФ»). Судопроизводство в Конституционном Суде в том случае начинается, когда, по мнению самого заявителя, существует противоречие между положениями Конституции и нормами закона, и не просто закона, а примененного в конкретном деле, которые, с его точки зрения, нарушают его конституционные права и свободы. В данном случае отсутствуют, так называемые, «препирательства» между реальными субъектами по поводу принадлежности или нарушения основных прав и свобод личности. Требования о прекращении их 
ущемления адресуются в целом государству, рассматриваемому не только как система органов, но и как социальный институт. Юридический конфликт в данном случае локализуется в нормативно-правовой сфере.

Российский законодатель связывает возникновение юридического конфликта между гражданином и государством в сфере конституционных правоотношений, вопервых, с изданием закона, нарушающего основные права и свободы личности, а вовторых, с применением или реальной возможностью применения его к конкретному лицу при разрешении некоторого правового вопроса правоприменительными органами.

При этом, конфликт по поводу ущемления законом конституционных прав и свобод граждан может возникнуть как на стадии правотворчества, так и на стадии применения права, он отражает своего рода цикл в жизни норм права, их развитие и функционирование. Важнейшей особенностью исследуемого авторами юридического конфликта является то обстоятельство, что он существует в общих (конституционных) правоотношениях, возникающих между гражданином и государством в целом, характеризующихся как отношения «власти - подчинения».

Таким образом, спор о праве возникает между личностью и государственным органом, издавшим закон, нарушающий конституционные права и свободы личности. Жалоба гражданина или объединения граждан, предъявленная в Конституционный Суд, содержит требование о защите основных прав и свобод граждан от нарушений их со стороны государства в лице высших органов Федерации или ее субъектов и одновременно является юридическим фактом, с которым закон связывает начало контрольной деятельности Конституционного суда по проверке соответствия закона Конституции.

Перейдем непосредственно к применению теста на пропорциональность при рассмотрении конституционных жалоб.

Принцип пропорциональности очень популярен в научной сфере и широко применяется судами. В общем виде принцип пропорциональности представляет собой тест из трех пунктов, с помощью которого оценивают:

a) подходит ли некоторая мера, устанавливающая ограничение прав человека, для достижения той или иной цели;

б) является ли она необходимой для этой цели;

в) не излишне ли она обременяет человека по сравнению с благами, которые призвана обеспечить.

Тест на пропорциональность позволяет оценить правомерность ограничения права и, соответственно, ответить на вопрос о том, может ли данный принцип быть полезен при «ограничении» одной из конкурирующих конституционных ценностей. Представляется, что может. Подтверждается это правовой теорией и судебной практикой.

Г.А. Гаджиев отмечает, что «принцип пропорциональности, являясь одной из конституционных ценностей, становится в конституционном праве универсальным методом решения юридических задач»].

При рассмотрении примеров и критериев выбора приоритетных конституционных ценностей отмечается, что в конституционных спорах неизбежны конфликты принципов и конфликты ценностей. Эти конфликты могут быть разрешены только путем исследования законодательных фактов, а не норм в «чистом виде». При этом, законодательные факты состоят не только из нормативного материала, но также из индивидуальных и общественных целей (интересов) и из разного рода ценностей. Соответственно, получается замкнутый круг: конфликты конституционных ценностей должны разрешаться посредством конституционных ценностей. Разрешению же ценностных конфликтов служат принцип пропорциональности и так называемое взвешивание ценностей. Однако ни взвешивание ценностей, ни принцип 
пропорциональности не отличаются простотой в применении и не ведут к точным и однозначным решениям.

Российские суды редко в своих решениях обращаются к тесту на пропорциональность. Руководствуется ли Конституционный Суд РФ принципом пропорциональности при рассмотрении конституционных жалоб?

Примерно в половине своих постановлений Конституционный суд прямо упоминает принцип пропорциональности (соразмерности), что существенно по сравнению с другими судами. Хотя Конституционный Суд не делает его основным подходом своей аргументации и не следует определенному алгоритму данного принципа, тем не менее, тесты пропорциональности имплицитно присутствуют в его решениях. Так, решая вопрос о том, затрагивает ли закон, примененный в конкретном деле, конституционные права заявителя (допустимость жалобы). Конституционный Суд, по сути, проводит тесты пропорциональности о том, имеет ли место вмешательство в конституционное право и осуществляется ли это вмешательство законом. При этом, к понятию «закон» Конституционный Суд подходит не формально, а содержательно, определяя в ряде случаев в качестве «закона» и постановления Правительства РФ]. Далее, Конституционный Суд определяет допустимость ограничения права законом в соответствии с конституционными целями, необходимость использованных государством мер и баланс частных и публичных интересов.

В то же время, анализ решений Конституционного Суда РФ, особых мнений судей Конституционного суда РФ к данным решениям показывает, что Конституционный Суд РФ при обосновании своих позиций, как правило, использует стандартные аргументы общего характера, в частности о необходимости достижения соразмерности при соблюдении интересов общества и условий защиты основных прав личности, то есть баланса конституционно защищаемых ценностей.

При этом, отсутствие у Конституционного Суда, своего рода, полномочий, не дает ему возможности продвинуться дальше определения соответствия ограничения права конституционным целям, поскольку абстрактное определение необходимости предусмотренных мер и баланса интересов или ценностей не выводит рассуждения за пределы теста легитимности цели вмешательства. В конечном итоге, Конституционный Суд имеет дело с абстрактными ценностями и интересами и по-своему их оценивает. Однако в рамках взвешивания такие ценности и интересы не могут учитываться.

Кроме того, принцип пропорциональности исключает подмену балансирования конкурирующих прав (третья стадия) допустимостью вмешательства, которая является лишь первой стадией пропорциональности, когда вмешательство в субъективное право соотносится с абстрактной целью. Балансирование имеет дело с конкретной правовой действительностью, которая открывается суду в качестве таковой по результатам исследования необходимости вмешательства (вторая стадия). Соответственно, балансирование конкурирующих прав осуществляется в конкретной правовой действительности, где последовательно определяется степень вмешательства в субъективное право, важность конкурирующего права или законного интереса и их баланс, то есть оправданность вмешательства в субъективное право для удовлетворения конкурирующего права или законного интереса (третья стадия).

В свете полномочий Конституционного Суда, применение теста пропорциональности является пригодным подходом правильного решения только в том случае, когда оспариваемый закон, примененный в конкретном деле, содержит меру непосредственного вмешательства в конституционное право, которая не направлена на конституционные цели либо выходит за их пределы. Учитывая абстрактность этих целей и опытность законодателя, вероятность того, что он предусмотрит меры, не соответствующие таким целям, ничтожна. Если же оспариваемый закон не содержит меру непосредственного вмешательства в конституционное право, то, с учетом 
полномочий Конституционного Суда, определение того, затронуто ли законом право заявителя (первый тест на пропорциональность), невозможно, а любое решение об этом ошибочно. Это приводит к тому, что значительное пространство нормативной материи оказывается вне зоны конституционного контроля над обеспечением государством конституционных прав.

По всей видимости, Конституционный Суд старается применять тест пропорциональности, но для этого его возможности ограничены. В то же время, у других судов соответствующие полномочия имеются, однако тест пропорциональности используется редко. Вместе с тем, при рассмотрении конституционных жалоб, использование теста на пропорциональность крайне затруднительно, в виду абстрактности рассматриваемых ситуаций.

$$
* * *
$$

1. Алекси Р. Сбалансированность, конституционный контроль и представительство / Р. Алекси// Сравнительное конституционное обозрение, 2006, N 2, С. 113-118.

2. Белов С.А. Рациональность судебной балансировки конституционных ценностей с помощью теста на пропорциональность/ С.А. Белов// Петербургский юрист, 2016, № 1, С. 63-75.

3. Гаджиев Г.А. Качество законов с российской точки зрения: доклад на ХІІІ Диалоге высших судов России и Германии (Москва, 31 мая - 1 июня 2012 г.)/ Г.А. Гаджиев// Доступ из справ.-прав. службы «КонсультантПлюс» (по состоянию на 18.01.2018)

4. Гюлумян В.Г. Принципы толкования Европейской конвенции прав человека (критика и защита)/ В.Г. Гюлумян// Журнал конституционного правосудия, 2015, N 3, С. 6-18

5. Доронина О.Н., Лучин В.О. Жалобы граждан в Конституционный суд РФ/ О.Н. Доронина, В.О. Лучин/ М.: Закон и право ЮНИТИ, 1998 г., 260 с.

6. Михайлов А.А. Принцип пропорциональности: сущность, практика применения Европейским судом по правам человека, Конституционным судом РФ и значение для совершенствования системы доказывания в современном уголовном процессе России/ А.А. Михайлов// Уголовная юстиция, 2016, № 1, С. 56-63.

7. Цакиракис С. Пропорциональность: посягательство на права человека?/ С. Цакиракис// Сравнительное конституционное обозрение, 2011, № 2, С. 47-66.

8. Шустров Д.Г. Essentiaconstitutionis: Конституция Российской Федерации в фокусе теорий конституции XX - XXI веков/ Д.Г. Шустров// Сравнительное конституционное обозрение, 2017, N 3, C. $71-90$.

\section{Денисова Е.Л. \\ Проблемы реституции национализированного имущества в России}

Ивановский государственный университет (Россия, Иваново)

doi:10.18411/spc-20-04-2018-08

idsp: 000001:spc-20-04-2018-08

Гражданскому праву, как и всякой отрасли права, присущи свои специфические начала - принципы. В ст. 35 Конституции РФ закреплён принцип неприкосновенности частной собственности: «Каждый вправе иметь имущество в собственности, владеть, пользоваться и распоряжаться им как единолично, так и совместно с другими лицами. Никто не может быть лишен своего имущества иначе как по решению суда». Правовая защита собственности - одна из важнейших целей гражданского законодательства.

Тем не менее, истории известен пример массового лишения права собственности - национализация в РСФСР, которая со временем распространилась на другие страны коммунистического блока. Этот процесс можно рассматривать, как пример попрания принципа неприкосновенности частной собственности, который, однако, является неизменным спутником такого коренного изменения в общественном строе, как социальная революция.

В 90-ых годах прошлого века в бывших республиках СССР произошла денационализация, однако проходила она разными путями. Россия провела непосредственную приватизацию имущества. Страны Прибалтики провели и 